\title{
Reclaiming Spaces of Energy Consumption through Rethinking Approaches to Rural Electrification in India
}

\author{
Manashvi Kumar* \\ Department of Revenue, Relief, Rehabilitation and Disaster Management, Government of Punjab, India
}

Submission: August 27, 2020; Published: August 31, 2020

*Corresponding author: Dr. Manashvi Kumar, Secretary, Department of Revenue, Relief, Rehabilitation and Disaster Management, Government of Punjab, Room no.7, Third Floor, Punjab Civil Secretariat, Chandigarh-160001, India

\begin{abstract}
The perception engages with the central theme of triggering an energy system change for providing energy access at the last mile. An energy system change is about managing a transition in terms of production of energy and its consumption. In order to do that, there is an imperative to conceptualize electricity provisioning and the associated politics in the field of socio-technical and sustainable transitions. The policy process needs to understand that rural energy ecosystems are plural and heterogeneous, based on specific renewable energy resource endowment, local resource base, as well as consumption patterns. As regards approaches to address needs for power for all in terms of energy access, a lot remains to be done beginning from assessment of local resource potential for localized, embedded, on-site generation of electricity. This calls for an ideological transformation to creation of a league of prosumers (producers who are consumers as well)
\end{abstract}

Keywords: Energy access; Energy system change; Transition; Socio-technical; Sustainable; Prosumers

\section{Opinion}

The rural energy landscape of India comprises a plural and complex heterogeneous mix of energy demand. Should there be an ideal case to be- access to modern energy services in rural areas become a perceptible reality in the times to come; the future of power systems shall rest upon twin dogmatic paradigms:

a) Comprehensive demand aggregation and profiling of a rural, domestic consumer situated in a geo-cultural, climatic zone/space and a distinct physiographic terrain, and

b) Local renewable energy resource assessment. This exercise should emphatically be for a given geographic territory and on a given temporal horizon. It should take into account seasonal variability as well. However, it is always easier said and remains a wishful thinking.

Can all of the technological options be accommodated, whether or not they are in sync with the existing, not so inter-dependent generation, transmission and distribution networks? Probably not. Power system configurations whether based upon renewables or brown-fuels have their intrinsic, conservative functionalities. The choice of having a balanced, optimized supply based on source coupling within a given territory, banks upon the concept of an embedded, local generation and distribution system, that could possibly run on "energy alloys (mixed sources of power generation)". The determining factor in the composition of this mix shall primarily

be the availability of local resource supplies. Further, this shall be affected by the techno-economic conditions for production, retention (islanding) and distribution of the energy produced. The current energy generation paradigm is very typical of an orthodox, top-down, target-based approach resulting in mass proliferation of mega-watt (MW) scale gigantic energy systems necessitating creation of energy intensive societies by boosting supplies.

Mega systems are not designed to cater to local, small and sporadic demands (loads or load centres). This policy framework is antagonistic to the philosophy of creation of local energy guilds effectively (presumably) run by prosumers (Toffler, 1980). As a result, rural electrification process still remains an unfinished agenda in India, being completely oblivious to the basic needs of the rural societies, and in terms of the effects of quantity and quality of service in their domestic lives. The ability of users to appreciate the intrinsic and extrinsic value of access to energy remains abysmally dismal. The rural, energy consumption ecosystem warrants an in-situ, longitudinal study. The provision 
of state subsidies stand on a slippery ground as there is lack of concurrence on profiling of rural, domestic demand for energy, regressively construed in terms of electricity distribution network extension. The rural, domestic- individual and community clusters (as users), and the productive-sector (energy intensive sector) users should be similarly placed and considered on principles of equity pricing in lieu of access to energy. As, every society makes an effort towards 'commodious living' in space and time, it is extremely important that incremental improvements in quality and reliability of energy services access be given its due.

A big push aimed at extension of rural electrification infrastructure in rural areas, increasing the visibility of rural electricity infrastructure by covering all below poverty line (BPL) families. It involved setting up a uniform village infrastructure at a community development (CD) block level, for catering to non-domestic demand for power. These initiatives, however, were all aimed at pushing through the overlapping extension activities proposed under different flagship programs for rural electrification. Nevertheless, quality and reliability of supply remained a serious un-addressed issue. Rural electrification, as a process, is prohibitively costly given the conditions of terrain and other locale-specific realities which are normally ignored. The process a lot of scope for recurring revision on account of the fact that 'the context gets missed out' quite often. There is still a dire need for creation of base line energy consumption data including terrain specific modelling.

An empirical approach for demand aggregation shall require creation of robust, autonomous institutions for data capture and analysis. The extension of the central grid for providing access shall remain the sole plausible option, till the time any alternative model for providing on-site generation and consumption of energy is designed. Any switchover to alternate energy systems and technologies that are 'contextually' grounded, and 'smaller in scale' would entail usage of distinctly disparate simulation tools for micro-planning. It is further necessary, that the planning tool must adept to local complexities and highlight them appropriately, rather than relying on secondary data from different agencies of the state.

The electricity sector follows mainly two distinguishing approaches for planning of rural electrification with a given time horizon - a) the so-called techno-economic approach, which aims only to optimize an economic criterion (objective function) by allowing narrow investment choice based on maximized generation of energy produced by limited non-comparative technologies, and b) the so-called multi-sector approach, which also entails an economic optimization, to say the least, identical to the previous one, but is vehemently skewed toward one particular energy source within the 'framework of nonconventional energy sector; driven largely by the reductionist 'quantitative' dimension of attaining massive (Gigawatt scale) targets. The focus which is primarily driven by the objective of creation of visible infrastructure in any given territory, given the associated constraints- political, technical, financial, and strategic. This approach is strongly symbolic in character, too locked in structurally in scope. It distances itself yet again from the 'innate, anthropogenic dimension of energy.' What is required, is an altogether different 'systems approach' to convert human (local) energy inaction to local (human) energy in action by tapping/ harnessing the local resource base. The focus needs to shift to localized production and consumption, driven by the concept of 'prosumerism' (producer becoming a consumer).

The aim of rural electrification planning is to fulfil the general objectives defined under the national electricity policy 2005. The overall purpose was to extend access to electricity within a given territory and within a given time horizon. However, this single, sovereign approach missed upon one essential aspect- integration of spatial planning, within the scope of rural electrification to increase the social and economic impact of the process. As a result, this program did not infuse confidence in the private sector. Thought it was visible, but it had no takers apart from the state utilities. As Lahimer et al. (2013) puts it- "rural electrification is a complicated issue because of user affordability, rural in accessibility and remoteness, low population densities and dispersed households, low project profitability, fiscal deficit, scarcity of energy sources, population growth, lack of professionalism and over-dependence on subsidies.

It is an accepted fact that the development of a sub-sectoral policy on rural electrification is conceived and designed by the 'MACRO' (the union) whereas, the responsibility for effective implementation of the policy lies upon 'MESO' (the state distribution utilities and the power/energy departments of the respective states). There is no involvement of the 'MICRO' (the III tier architecture of local governance) whatsoever. Rural electrification has been since decades, the sole imperative and prerogative of the central government. The electricity act, 2003 has been instrumental in overhauling the 'mega-picture' of the electricity sector, however, a lot remains to be done with regard to the approach towards rural electrification, especially decentralized distributed generation (DDG) based on nonconventional sources of energy including off-grid, stand-alone systems. There is a pressing need for an enabling environment for active community partnership, both as generators and consumers of electrical energy. A greater precision is required in the enabling provisions of regulatory policies and programs of rural electrification as a whole.

The contemporary institutional set up, the central agencies and their functional structures need to adopt a more granular approach in terms of engaging with the MESO in a reciprocal manner-to reduce institutional compartmentalization. This shall involve a closer association with the MICRO- the three-tier local governance structure (the district, the block and the village). Local understanding of the basic needs of any given geo-spatial terrain, 
in terms of demand aggregation and its subsequent profiling should be effectively through the MICRO- anon-existent entity at present vis-à-vis energy governance framework.

There is a strongly felt need for- a) decentralization, delegation, and devolution at the level of 'MESO' directed towards 'MICRO' all along the different phases as a sub-sectoral strategy, b) planning and, c) investment programming and execution. Thus, there is a much-desired push in terms of unequivocal sharing of responsibilities between the 'entities' to be entrusted with this paradigmatic shift. There is even a greater need to build capacities in terms of boosting human capital allow local communities to have a greater choice in terms of local generation and distribution planning. This ought to be commensurate with, the general 'tendency' at the top towards multi-sector collaboration in terms of energy-mix (renewables and conventional fuels). However, whether the proposed endeavour shall progressively lead to decompartmentalization in electrification (energy) planning and execution of small projects, at the 'MICRO' level between the key actors and rural development sectors shall primarily depend upon norms of reciprocity amongst the actors, and the networks of civic engagements that evolve later between actors and the enabling agents.

The existing framework is closed for any lateral substitution for accelerating the process of rural integration especially in terms of openings for alternate sources of energy, open access to the distribution network, alternate tariff structure etc. Consequently, in the interest of optimizing the access to electricity for all, the need is to first identify and establish the sufficient and good reasons for this policy dose. What should be the drivers? Electricity has the potential to create user-value by broadening the perception of a 'product experience' rather than just 'object interaction' (passive consumerism). However, the Indian experience of rural electrification is reflective of the fact that development work typically focuses on economic and physical aspects of development and often neglects the needs of the local communities that are affected by it.

*The views expressed are personal and exclusive in character, for an academic discourse (Author).
Your next submission with Juniper Publishers will reach you the below assets

- Quality Editorial service

- Swift Peer Review

- Reprints availability

- E-prints Service

- Manuscript Podcast for convenient understanding

- Global attainment for your research

- Manuscript accessibility in different formats ( Pdf, E-pub, Full Text, Audio)

- Unceasing customer service

Track the below URL for one-step submission https://juniperpublishers.com/online-submission.php 